\title{
Canned chicken products ${ }^{1,2}$
}

\author{
Fred Fermández-Coll ${ }^{3}$, Teresita Rodríguez-León \\ and Irvis Pagán-Pinto
}

\begin{abstract}
Production and consumption of chicken in Puerto Rico has been increasing. The amount of imported chicken, however, is still too high. To provide alternatives that can be used to diversify and increase local poultry production, convenience canned products were developed. These included fricassee, patties, meatballs in tomato sauce, stewed gizzards and a base concentrate for rice dishes. Results indicated that the products developed were rated acceptable by the taste panel. This is indicative that the canned chicken products developed were good quality foods that thus have a market potential. Since these products were formulated as high quality foods, production costs are high.
\end{abstract}

\section{RESUMEN}

Productos enlatados de pollo

Tanto la producción como el consumo de pollo en Puerto Rico ha venido aumentando. Sin embargo, la cantidad de pollo que se importa a la isla es todavía alta. A manera de proveer alternativas que puedan utilizarse para diversificar y expandir la producción local de pollos, se desarrollaron varios productos enlatados. Estos incluyeron fricasé, hamburgesas ("patties"), albóndigas en salsa de tomate, mollejas guisadas y una base concentrado para platos con arroz. Un panel de catadores consideró aceptables los productos desarrollados. Esto indica que estos productos de pollo enlatados son alimentos de buena calidad, los cuales tienen un potencial de mercado. Como estos productos se formularon como alimentos de alta calidad, su costo de producción es elevado.

\section{INTRODUCTION}

For fiscal year 1988-89, the production of broiler chickens contributed $10.94 \%$ to the gross agricultural income of Puerto Rico, which was $\$ 731$ million (8). Preliminary figures indicate that for fiscal year 1989-90, the gross agricultural income totaled $\$ 721$ million, $\$ 77$ million (or 10.68\%) of

'Manuscript submitted to Editorial Board 18 October 1991.

${ }^{2}$ Authors wish to thank Mrs. Isabel Beauchamp de Caloni for performing, analyzing and interpreting the sensory evaluation of the experimental samples and for her review of this manuscript.

${ }^{3}$ Associate Food Microbiologist, Laboratory of Food Technology.

${ }^{4}$ Research Associate, Laboratory of Food Technology.

${ }^{5}$ Laboratory Technician, Laboratory of Food Technology. 
which corresponded to broiler production (4). Per capita chicken consumption in Puerto Rico for 1989-89 was $74.8 \mathrm{lbs}$. This figure is $3 \mathrm{lbs}$ more than the per capita consumption for $1987-88$ and $13.3 \mathrm{lbs}$ more than for 1984-85 (8).

These data indicate that chicken production constitutes an important source of agricultural income and that chicken consumption is steadily increasing in Puerto Rico. Since the poultry industry's drive in the $90 \mathrm{~s}$ will continue to target value-added merchandising (3), it seems reasonable to conclude that production of processed chicken products would foster the persistence of this observed steady increase in chichen production and consumption in Puerto Rico.

Development of refrigerated and frozen chicken products has probably been the most common way of adding value to chicken production. The process of canning furnishes additional alternatives to add value to chicken production, with the advantage that such products do not require refrigeration during warehousing, distribution, retail and consumer storage after purchase. As an example, both whole chickens and chicken fricassee have been canned and studied elsewhere $(5,6)$. Many different kinds of canned chicken products are currently available in any modern supermarket.

The purpose of this study was to develop canned chicken products which could be produced locally and add value to some of the current chicken production. The products developed included fricassee, patties, meatballs in tomato sauce, stewed gizzards and a base concentrate for rice dishes.

\section{MATERIALS AND METHODS}

\section{Fricassé}

Twenty pounds $(9.2 \mathrm{~kg})$ of chicken breasts was purchased locally. Each breast was skinned and cut in pieces 2.5 to 3.0 in $(6.4$ to $7.6 \mathrm{~cm})$ long (average weight of each piece was $1.7 \mathrm{oz}$ or $48.3 \mathrm{~g}$ ).

Green peppers $(1.8 \mathrm{lb}$ or $817.2 \mathrm{~g}$ ) and sweet peppers ( $4.2 \mathrm{oz}$ or 119.3 g) were seeded and uniformly mixed in a blender together with $0.6 \mathrm{oz}$ $(17.0 \mathrm{~g})$ coriander leaves, $2.4 \mathrm{oz}(68.2 \mathrm{~g})$ fresh garlic, $7.1 \mathrm{lb}(3.2 \mathrm{~kg})$ onions and $10.5 \mathrm{oz}(298.2 \mathrm{~g}$ ) corn oil. This mixture was then cooked in an open steam-jacketed kettle for $8 \mathrm{~min}$. After this cooking, the temperature of the mixture was $160^{\circ} \mathrm{F}\left(71.1^{\circ} \mathrm{C}\right)$.

After the above mixture was precooked, $1.6 \mathrm{lb}(726.4 \mathrm{~g}$ ) tomato paste was added and all thoroughly mixed. The chicken pieces were added at this point together with $2.8 \mathrm{oz}(79.5 \mathrm{~g})$ salt, $0.6 \mathrm{oz}(17.0 \mathrm{~g})$ oregano, 0.24 oz $(6.8 \mathrm{~g})$ Bijol seasoning (mixture of corn flour, annatto, ground cumin seed and certified yellow and red colors), $1.2 \mathrm{lb}(544.8 \mathrm{~g}$ ) "alcaparrado" 
J. Agric. Univ. P.R. voL. 77, No. 3-4, JULY/OCTOBER, 1993139

(caper-olive mix), $0.1 \mathrm{oz}(2.8 \mathrm{~g}$ ) bay leaves, $4.5 \mathrm{lb}(2.0 \mathrm{~kg})$ pimientos, 2.7 $\mathrm{lb}(1.2 \mathrm{~kg})$ sweet peas, $1.9 \mathrm{lb}(862.6 \mathrm{~g})$ cooking wine, $16.4 \mathrm{lb}(7.5 \mathrm{~kg})$ water and $10.3 \mathrm{lb}(4.7 \mathrm{~kg})$ cut potatoes which had been blanched for $2 \mathrm{~min}$ in a boiling $1 \%$ citric acid solution. The ingredients were cooked for $20 \mathrm{~min}$. At the end of this cooking period, the temperature of the mixture was $200^{\circ} \mathrm{F}\left(93.3^{\circ} \mathrm{C}\right)$ and the internal temperature of the chicken pieces had reached approximately $160^{\circ} \mathrm{F}\left(71.1^{\circ} \mathrm{C}\right)$. Evaporation water was compensated for by measuring the level of the mixture before and after cooking and adding tap water accordingly. The mixture was then allowed to again reach $200^{\circ} \mathrm{F}^{\prime}\left(93.3^{\circ} \mathrm{C}\right)$.

Plain $303 \times 406$ tin cans were each filled with three pieces of the cooked chicken with the balance in hot $\left(200^{\circ} \mathrm{F}\right.$ or $\left.93.3^{\circ} \mathrm{C}\right)$ fricassee mixture up to a total net weight of $1 \mathrm{lb}(454 \mathrm{~g})$. Cans were sealed and thermally processed in a still retort at $250^{\circ} \mathrm{F}\left(121^{\circ} \mathrm{C}\right)$ for $84 \mathrm{~min}$ (Note: the thermal processes used in this study were determined by us solely for experimental purposes. For any commercial application of the canned products described in this study, certified thermal processes must be obtained from a process authority recognized by the U.S. Food and Drug Administration).

\section{Patties}

Thirty pounds $(13.6 \mathrm{~kg})$ chicken thighs and legs was purchased locally, skinned and boned by hand. Resulting bones were boiled in water until the adhered meat could be removed.

One and a half pound $(681 \mathrm{~g}$ ) giblet (mix of heart, liver and gizzard) was boiled in water for $20 \mathrm{~min}$. The boiled giblet, together with the meat removed from the boiled bones, was ground in a meatgrinder with a $1 / 4$ in $(0.64 \mathrm{~cm})$ diameter plate.

The chicken skin previously removed was boiled in water until tender and ground in a grinder with a $1 / 8$ in (0.32 in) diameter plate. All boned raw meat was ground with a $1 / 4$ in (0.64 in) diameter plate. This ground raw meat, together with the ground boiled skin, giblet and meat removed from bones, was thoroughly mixed.

To this mixture, $3.1 \mathrm{lb}(1.4 \mathrm{~kg})$ onion, $0.4 \mathrm{oz}(11.8 \mathrm{~g})$ black pepper, $1.5 \mathrm{lb}(681 \mathrm{~g})$ raw egg, $9.6 \mathrm{oz}(272.6 \mathrm{~g})$ salt and $3.9 \mathrm{lb}(1.8 \mathrm{~kg})$ eracker meal were added and vigorously mixed together. Four oz (113.6 g) patties were formed by hand, frozen in a plate freezer at $-40^{\circ} \mathrm{F}\left(-40^{\circ} \mathrm{C}\right)$ and stored frozen at $-10^{\circ} \mathrm{F}\left(-23.3^{\circ} \mathrm{C}\right)$.

Fourteen thawed $\left(80^{\circ} \mathrm{F}\right.$ or $\left.26.7^{\circ} \mathrm{C}\right)$ patties per can were placed in plain $404 \times 700$ tin cans, packed in boiling $2 \%$ brine up to an average net weight of $3.2 \mathrm{lb}(1,450.5 \mathrm{~g})$, sealed and thermally processed in a still retort for $150.5 \mathrm{~min}$ at $250^{\circ} \mathrm{F}\left(121^{\circ} \mathrm{C}\right)$. 
Meatballs

The same formulation and procedure as for the patties was followed in making the meatballs. The difference was that instead of shaping 4-oz $(113.6 \mathrm{~g})$ patties, $0.5-0 \mathrm{z}(14.2-\mathrm{g})$ balls were formed.

A sauce was prepared by mixing $3.9 \mathrm{lb}(1.8 \mathrm{~kg})$ tomato paste, $3.4 \mathrm{oz}$ $(96.6 \mathrm{~g})$ dehydrated onion, $0.1 \mathrm{oz}(2.8 \mathrm{~g})$ garlic powder, $0.02 \mathrm{oz}(0.6 \mathrm{~g})$ bay leaves, $1.5 \mathrm{oz}(42.6 \mathrm{~g})$ olive oil, $0.2 \mathrm{oz}(5.7 \mathrm{~g})$ oregano, $1.4 \mathrm{oz}(39.8 \mathrm{~g})$ salt, $1.2 \mathrm{oz}(34.1 \mathrm{~g})$ refined sugar, $0.06 \mathrm{oz}(1.7 \mathrm{~g})$ Cayenne red pepper and $5.6 \mathrm{lbs}(2.5 \mathrm{~kg})$ tap water. The blended mixture was heated in an open steam-jacketed kettle until the mixture reached a temperature of $200^{\circ} \mathrm{F}$ $\left(93.3^{\circ} \mathrm{C}\right)$.

Sixteen thawed $\left(80^{\circ} \mathrm{F}\right.$ or $\left.26.7^{\circ} \mathrm{C}\right)$ meatballs per can were placed in plain $303 \times 406$ tin cans, filled with the hot $\left(200^{\circ} \mathrm{F}\right.$ or $\left.93.3^{\circ} \mathrm{C}\right)$ sauce up to an average net weight of $1 \mathrm{lb}(454 \mathrm{~g})$, sealed and thermally processed in a still retort at $250^{\circ} \mathrm{F}\left(121^{\circ} \mathrm{C}\right)$ for $95.5 \mathrm{~min}$.

\section{Base concentrate}

Eight pounds $(3.6 \mathrm{~kg})$ of chicken breasts was purchased locally. Each breast was skinned and cut in pieces 1.5 to 2.0 in $(3.8$ to $5.1 \mathrm{~cm}$ ) long (average weight of each piece was $1.1 \mathrm{oz}$ or $31.3 \mathrm{~g}$ ).

Green peppers (12.8 oz or $363.5 \mathrm{~g}$ ) and sweet peppers (1.9 oz or 54.0 g) were seeded and uniformly mixed in a blender together with $1.5 \mathrm{oz}$ $(42.6 \mathrm{~g})$ fresh garlic, $3.2 \mathrm{lb}(1.5 \mathrm{~kg})$ onions, $0.5 \mathrm{oz}(14.2 \mathrm{~g})$ coriander leaves and $2.9 \mathrm{oz}(82.4 \mathrm{~g})$ corn oil. This mixture was then cooked in an open steam-jacketed kettle for $8 \mathrm{~min}$. After this cooking period, the temperature of the mixture was $160^{\circ} \mathrm{F}\left(71.1^{\circ} \mathrm{C}\right)$.

After the above mixture was precooked, $1.8 \mathrm{lb}(817.2 \mathrm{~g})$ tomato paste was added and all was thoroughly mixed. The chicken pieces were then introducecl together with $0.3 \mathrm{oz}(8.5 \mathrm{~g})$ oregano, $1.1 \mathrm{lb}(500 \mathrm{~g})$ "alcaparrado" (caper-olive mix), $3.7 \mathrm{oz}(105.1 \mathrm{~g})$ salt and $4.2 \mathrm{lb}(1.9 \mathrm{~kg}$ ) water. All these ingredients were cooked for $20 \mathrm{~min}$, at the end of which period the temperature of the mixture was $200^{\circ} \mathrm{F}\left(93.3^{\circ} \mathrm{C}\right)$ and the internal temperature of the chicken pieces had reached approximately $160^{\circ} \mathrm{F}$ $\left(71.1^{\circ} \mathrm{C}\right)$. Evaporation water was compensated for by measuring the level of the mixture before and after cooking and adding tap water accordingly. The mixture was then allowed to again reach $200^{\circ} \mathrm{F}\left(93.3^{\circ} \mathrm{C}\right)$.

Plain $303 \times 406$ tin cans were each filled with 5 pieces of the cooked chicken with the balance in hot $\left(200^{\circ} \mathrm{F}\right.$ or $\left.93.3^{\circ} \mathrm{C}\right)$ concentrate mixture to a total net weight of $1 \mathrm{lb}(454.4 \mathrm{~g})$. Cans were sealed and thermally processed in a still retort at $250^{\circ} \mathrm{F}\left(121^{\circ} \mathrm{C}\right)$ for $84 \mathrm{~min}$. 
J. Agric. Univ. P.R, vol. 77, No. 3-4, JULY/OCTOBER, 1993141 Stewed gizzards

Green peppers ( $1.9 \mathrm{lb}$ or $862.6 \mathrm{~g}$ ) and sweet peppers $(4.5 \mathrm{oz}$ or 127.8 g) were seeded and uniformly mixed in a blender together with $7.6 \mathrm{lb}$ $(3.5 \mathrm{~kg}$ ) onions, $0.2 \mathrm{oz}(5.7 \mathrm{~g})$ coriander leaves and $6.4 \mathrm{oz}(181.8 \mathrm{~g})$ corn oil: This mixture was then cooked in an open steam-jacketed kettle for 8 min, After this cooking period the temperature of the mixture was $160^{\circ}$ $\mathrm{F}\left(71.1^{\circ} \mathrm{C}\right)$.

After the above mixture was precooked, $1.7 \mathrm{lb}(771.8 \mathrm{~g})$ tomato paste, $0.06 \mathrm{oz}(1.7 \mathrm{~g})$ bay leaves, $0.3 \mathrm{oz}(8.5 \mathrm{~g})$ garlic powder, $0.3 \mathrm{oz}(8.5 \mathrm{~g})$ oregano, $3.2 \mathrm{oz}(90.9 \mathrm{~g})$ salt, and $7.9 \mathrm{lb}(3.6 \mathrm{~kg})$ water were added and all thoroughly mixed. All this was cooked for $20 \mathrm{~min}$, at the end of which period the temperature of the mixture was $200^{\circ} \mathrm{F}\left(93.3^{\circ} \mathrm{C}\right)$. Meanwhile, $20 \mathrm{lb}(9.1 \mathrm{~kg})$ frozen chicken gizzards was boiled in $2 \%$ brine until the internal temperature of the gizzards was approximately $130^{\circ} \mathrm{F}\left(54.4^{\circ} \mathrm{C}\right)$.

Plain $303 \times 406$ tin cans were each filled with $8 \mathrm{oz}(227 \mathrm{~g})$ boiled gizzards with the balance in hot $\left(200^{\circ} \mathrm{F}\right.$ or $\left.93.3^{\circ} \mathrm{C}\right)$ sauce up to a total net weight of $1 \mathrm{lb}(454 \mathrm{~g})$. Cans were sealed and thermally processed in a still retort at $250^{\circ} \mathrm{F}\left(121^{\circ} \mathrm{C}\right)$ for $77 \mathrm{~min}$.

\section{Product Evaluation}

All canned products developed in this study were subjected to bacteriological analysis immediately after processing and after 15-day incubation at room temperature $\left(77\right.$ to $186^{\circ} \mathrm{F}$ or 25 to $\left.30^{\circ} \mathrm{C}\right)$. Official methods of analysis for low-acid canned foods were used (2).

After the bacteriological analyses proved that products were commercially sterile, they were subjected to a taste panel evaluation.

\section{RESULTS AND DISCUSSION}

All bacteriological analyses done the same day of processing and 15 days afterwards proved the products to be commercially sterile (data not presented). Table 1 summarizes the results obtained in the sensory evaluation of the canned chicken patties. Plain patties were not accepted in appearance, flavor and general acceptability by the taste panel (mean values below 4.00). Texture, however, was found acceptable.

Because patties contained an average $5 \%$ giblet by weight, flavor and, to a lesser extent, appearance were adversely affected when served by themselves. When served in a bun with fried onions, lettuce and tomato slices, the patties were acceptable; thus the flavor and appearance improved considerably. This was due to the masking effect that the other ingredients provided when the patty served as a burger. For the formulation used (which included giblet), the product should be consumed as a 
TABLE 1.-Sensory evaluation of canned chicken patties'

\begin{tabular}{lcccc}
\hline & \multicolumn{4}{c}{ Mean values: $^{*}$} \\
\cline { 2 - 5 } Sample & Appearance & Flavor & Texture & $\begin{array}{c}\text { General } \\
\text { acceptability }\end{array}$ \\
\hline$\# 1^{\text {: }}$ & 3.66 & 2.50 & 4.17 & 2.83 \\
$\# 2$ & 4.23 & 4.31 & 4.77 & 4.31 \\
\hline
\end{tabular}

'For evaluation, patties were grilled at $176.7^{\circ} \mathrm{C}\left(350^{\circ} \mathrm{F}\right)$ for 3 minutes on each side.

26 - point scale: $6=$ like very much; $1=$ do not like. Mean values above 4.00 are considered acceptable. These mean values represent average of 10 samples.

"Sample \#1 = plain chicken patties.

Sample $\# 2$ = patties evaluated in a burger bun with lettuce, fried onion and tomato slices.

burger and not by itself. Other investigators also have found different acceptability ratings in chicken patties with different formulations $(1,7)$.

Results of sensory evaluations of the other canned chicken products appear in table 2. All products developed were considered acceptable by the taste panel. Generally, the stewed gizzards and the meatballs in tomato sauce exhibited the highest ratings in appearance, while receiving the lowest ratings in flavor among all products evaluated. The fricasseé and the rice made with the base concentrate were about equal in their ratings for both appearance and flavor.

These results indicate that the canned chicken products developed were of good quality and that they thus have a market potential. Production costs would be a major drawback encountered for successful marketing. Specialized markets willing to pay higher prices for quality products could be sought. Also, ingredient substitution or omission to lower pro-

TABLE 2.-Sensory evaluation of various canned chicken products

\begin{tabular}{|c|c|c|c|c|c|}
\hline \multirow[b]{3}{*}{ Chicken Products } & \multicolumn{5}{|c|}{ Mean values' } \\
\hline & \multicolumn{2}{|c|}{ Appearance } & & \multicolumn{2}{|c|}{ Flavor } \\
\hline & 0 Days & 15 Days & & 0 Days & 15 Days \\
\hline Fricassée & 1.20 & 1.31 & & 1.00 & 1.10 \\
\hline $\begin{array}{l}\text { Rice cooked with the } \\
\text { base concentrate }\end{array}$ & 1.33 & 1.25 & & 125 & 117 \\
\hline $\begin{array}{l}\text { Stewed gizzards } \\
\text { Meatballs in }\end{array}$ & 1.25 & 1.50 & & 0.75 & 0.63 \\
\hline tomato sauce & - & 1.55 & & - & 1.00 \\
\hline
\end{tabular}

$1+2,-2$ scale: $+2=$ very acceptable; $+1=$ acceptable; $0=$ questionable; $-1=$ slightly unacceptable; $-2=$ not acceptable. Mean values above 0.5 are considered acceptable. These mean values represent the average of 10 samples.

${ }^{2}$ For evaluation, the whole content of the can of concentrate was mixed with $0.75 \mathrm{lbs}$ $(1.65 \mathrm{~kg})$ water, $0.75 \mathrm{lbs}(1.65 \mathrm{~kg})$ rice, and stove top-cooked until rice was tender. 
J. Agric. Univ. P.R. vOL. 77, NO. 3-4, JULY/OCTOBER, 1993143

duction costs could be considered by whoever produces these products commercially. This practice, however, would be at the expense of lowering product quality.

\section{LITERATURE CITED}

1. Ande, C. F., D. L. Huffman and J. C. Cordray, 1984. Edible yield and characteristics of patties manufactured from two types of chicken carcasses. Poultry Sci. 63: 217580.

2. Association of Official Analytical Chemists, 1984. Bacteriological Analytical Manual, 6th ed. AOAC, Arlington, Virginia.

3. Cannon, C., 1991. Poultry's challenge - new products demand more value and convenience. Food Processing 52(1): 84-90.

4. Department of Agriculture, Office of Agricultural Statistics. Yearbook of Agricultural Statistics 1989-90.

5. Lange, H. J., 1980. The composition of chicken or poultry fricassee. Fleischwirthschaf 60 (1): 72-74, 103. Abstract in FSTA (1980) 12: 7S1147.

6. Marion, J. E., T. S. Boggess and J. G. Woodroof, 1964. Pretreatment and processing methods of canned whole chickens, Poultry Sci. 42: 1097-1101.

7. Roland, L. M., S. C. Seideman, L. S. Donnelly and N. M. Quenzer. 1981. Physical and sensory properties of chicken patties made with varying proportions of white and dark spent fowl muscle. J. Food Sci. 46: 834-37.

8. Reyes, J., 1990. Aves y Cerdos. En: Empresas Agrícolas de Puerto Rico: Situación y Perspectivas - 1988-89. Esta. Exp. Agric. Univ. P.R. 